\title{
Itsbat (Law Stipulation) for Mixed Marriage in Indonesia Tourism Destination
}

\author{
S Khosyi'ah $^{1}$, R W Sururie ${ }^{2}$, A T Fuadah ${ }^{3}$, A Sholeh $^{4}$ \\ Faculty of Shari'ah and Law, UIN Sunan Gunung Djati Bandung, Indonesia ${ }^{1-4}$ \\ siah.khosyiah@uinsgd.ac.id $\left.{ }^{1}\right\}$
}

\begin{abstract}
This study aims to describe the itsbat marriage and judicial legal considerations in granting itsbat marriage to mixed marriages in tourist areas in Indonesia in relation to material rights after the marriage has legal force. This study uses a normative juridical method with a qualitative approach, primary data sources in the form of reasons and judicial legal considerations that are related to this research, while secondary data sources, in the form of books that have relevance to research. Data collection techniques in addition to interviews with judges that establish its marriage rights for mixed marriage applications in tourist areas in Indonesia are also related literature. The data analysis in this study is a qualitative analysis with a normative juridical approach. The results showed that juridically itsbat mixed marital marriage in tourist areas in Indonesia legal considerations of religious court judges not only use written law as in the Compilation of Islamic Law Article 3 paragraph (3) letter e which is used as a reason ijtihad judges in granting itsbat marriage of mixed marriages in tourist areas in Indonesia, but more emphasis on other aspects so that from various formulations of judges' consideration, disparities can be seen from one another. A marriage that has legal certainty (principle of legal security and rechtzheheid), the state guarantees the rights and obligations of every citizen including those who engage in mixed marriages in tourist areas in Indonesia, the effect of the itsbat marriage about the right and obligation to strengthen marriage itself rights and obligations will arise which have to do with material rights, for example, the right to livelihood, rights to joint property, inheritance rights, and so on.
\end{abstract}

Keywords: Itsbat, Marriage, Juridical

\section{Introduction}

In Indonesia, the long history of the birth of Law No. 1 of 1974 gave not only legal force about marriage procedures for Islamic society but also gave formal legal about the legality of marriage including that marriage must be recorded by the marriage registration. Marriage registration is important because it affects the material rights of husband and wife and children born from the marriage. In Law No. 1 of 1974 Article 2 paragraph (2), it is explained that each marriage must be recorded according to the prevailing laws and regulations. The meaning of this article illustrates that marriage will have legal power if it is done based on religious law and recorded. This matter is also explained in the Compilation of Islamic Laws article 5 and 6. The consequences of such registration will also be the birth of a marriage certificate book. 
However, with various marital problems in the community, the recording and marriage certificate are still a lot of problems, which is why other legal efforts such as itsbat marriage are forgotten.

Provisions governing the marriage of Muslims in Indonesia, in addition, there are provisions concerning legislation that require marriage registration so that with that marriage will get a formal marriage certificate, there are other provisions governing itsbat marriage namely; constitute legal remedies that can be carried out to obtain state recognition for marriages that are not recorded through the filing of marriage decisions. In Article 7 paragraph (2) the Compilation of Islamic Law states that; "In the event that a marriage cannot be proven by a marriage certificate, the marriage certificate can be submitted to the Religious Court" and in paragraph (3) it is stated; "the marriage certificate which can be submitted to the Religious Court is limited to matters relating to:

1. Marriage in the context of marriage settlement;

2. Missing marriage certificate;

3. There are doubts about the validity of one of the terms of marriage;

4. The existence of a marriage before the enactment of Act No. 1 of 1974; and

5. Marriage is carried out by those who do not have a marriage obstacle according to Law number 1 of 1974.

The purpose of marriage in Islam has an impact on the importance of the provisions that must be fulfilled when people will marry as a form of agreement between God and humans and between humans involved in it, of course, so that the agreement becomes strong then certain conditions are needed. During the time of the Islamic scholars, for example, the marriage became an interesting study so that the scholars at that time gave their interpretation and provisions of the requirements related to marriage. Hanafi schools, Maliki schools, Syafi'i schools, and Hambali schools interpret that marriage results in legitimate ownership of both husband and wife relations and material rights[1]. In order for a relationship between rights and obligations to be determined, there must be a dowry to be fulfilled by the prospective bridegroom. Abu Hanifah determines that the dowry must be paid a maximum of ten dirhams, Imam Malik determines four dirhams, Imam Syafi'i determines the dowry can be determined by everything that is valued in the sale and purchase, and Imam Ahmad Ibn Hambali is of the same opinion as Imam Syafi'i[1].

The research was conducted by Dian Syafriyanto, with the title of the research: "Implementation of Marriage Marriage at the Semarang Religious Court After the Enactment of Law Number 1 of 1974." The results of the study illustrate that the case of marriage is proposed voluntarily and can be filed in a religious court. The submission can be carried out by parties who have a legal position based on the provisions of Article 7 paragraph (4) Compilation of Islamic Law accompanied by legal facts and strong evidence that a marriage has been carried out by not having a marriage certificate as the basis for the stipulation of marriage. By law, Itsbat marriage can give rise to the rights and obligations of husband and wife and the rights of children born from the marriage legally in civil rights[2].

Nur RahmahYunus, Research entitled "Marriage Approval Process in Religious Courts," the study illustrates that marriages conducted under the hand can be legalized to the local Religion Court, where seeking justice is domiciled. Its marriage certificate was granted by the Religious Court by looking at the mercy of the negligence of the Marriage Registrar because it was not registered in the marriage book at the Office of Religious Affairs. The submission process was in line with the legislation that applies both to Indonesian citizens living in Indonesia and living abroad[3]. 
Mariam Yasmin, "Due to Mixed Marriage of Children and Assets Obtained Before and After the Marriage of Indonesian Malaysian Comparative Study." The results of the study illustrate that people's understanding of mixed marriages needs to be increased, lack of understanding of the community has an impact on the legal rights of children, including property produced before and after the marriage takes place, because each country has laws and regulations that apply to mixed marriages, in Indonesia have laws that are more flexible compared to Malaysia[4].

In contrast to previous studies, the research conducted was more touching on the whole about itsbat marriage conducted in mixed marriages for foreign nationals who are married to women who are Indonesian citizens in tourist areas in Indonesia, this is done because it is suspected that many foreign nationals marry women of dignity the Indonesian state in the region, including the presentation of civil rights that can be protected legally which has not been regulated in Law Number 1 of 1974 and Law Number 62 of 1958 concerning citizenship which is considered unable to accommodate the interests of the parties that are marriages. mix especially wives and children including child nationality.

From the background of the problem, it can be formulated that its marriage marriage in mixed marriages is carried out by married couples whose marriages are not recorded in the religious affairs office (KUA) with legal considerations that are not in accordance with the reasons for itsbat marriage in Law Number 1 of 1974 and Compilation Islamic law also does not protect the material rights in the laws governing mixed marriages in Indonesia. To be more directed, the formulation of the problem can be explained in the following research questions:1. How is the concept of itsbat marriage in the laws that apply in Indonesia? 2. What is the legal reason for mixed marriages as a legal consideration of its marriage by a judge in a religious court in Indonesia? 3. How is itsbat marriage process for mixed marriages in tourist areas in Indonesia? 4. How is the effect of its marriage from mixed marriages on rights and obligations related to civil rights and obligations?

\section{Method}

The stages of the research process carried out are described in this chapter. The first description is explained about research methods, research approaches, research objects. The next section describes the data collection and processing techniques. Here also explained the ways of collecting data, so that valid data is obtained. In the final section is explained about data analysis. The research method is basically a scientific way to get certain goals and uses, based on that there are four keywords that need to be considered, namely, scientific, data, purpose and usefulness.

Research related to the title of marriage itsbat on mixed marriages can be included in the field of Islamic law research and social institutions and this study aims to uncover the application of law and legal discovery by judges that are taken into consideration in the decisions of Religious Court judges in particular regarding itsbat marriage for juridical mixed marriages normative, meaning that this research will be seen from the values developing in Islamic law, including in the view of legislation. And also, the jurisprudence that can be used as a legal source in deciding the same case that comes later. For that reason, this study uses a normative juridical method and descriptive analysis with a qualitative approach.

Sources of data in this study use primary data sources and secondary data sources. The primary data source is the perpetrator of marriage from mixed marriages and legal findings by a judge related to the marriage itsbat of mixed marriages in the form of judges' decisions. And secondary data sources are books and other literature that has to do with religious differences 
in inheritance and literature on religious justice. The type of data in this study uses a type of qualitative data collected directly from the data source and has coherence with the research theme namely itsbat marriage for mixed marriages in tourist areas in Indonesia.

Data analysis is a process of organizing and sorting data into patterns, categories, and units of basic descriptions so that themes can be found, and working hypotheses can be formulated, which can be used as conclusions[5]. This study uses qualitative analysis because the available data is in the form of qualitative data on matters that are the basis of the judge's judgment in deciding the itsbat marriage at on mixed marriages. The model used is a qualitative data analysis of the flow model, in which the analysis is carried out through three channels, which include data reduction, data presentation, and conclusion drawing. Data reduction is an electoral process, focusing attention on simplifying and transforming data regarding the marriage case of a mixed marriage. Data presentation is carried out in order to understand the collected information which gives the possibility of conclusions (verification).

The conclusions are drawn in stages, through temporary conclusions to get to the final conclusion that has high validity, therefore, data analysis is carried out continuously throughout the study. Therefore, the analysis of this research was carried out since the study began until it was concluded to draw conclusions [verification] based on what was found in data reduction and data presentation, if the conclusion was felt to be unsatisfactory because there was a lack of data in the reduction and presentation of data, it would be collecting data repeatedly.

\section{Result and discussion}

Indonesia is a country that consists of several islands that are attractive and unique bargaining power complete with amazing nature as well as a variety of culinary; this uniqueness becomes its own power for foreign tourists to come to Indonesia with a short time. There are several reasons foreign tourists come to Indonesia as one of the best destinations in the world, among others: a stunning destination, from the coast to the top of the mountain; sunrise is stunning; delicious and varied cuisine; friendly residents; and culture that is diverse and is the wealth of the Indonesian people[6]. Natural conditions that attract foreign tourists to come to Indonesia have an impact on social interaction between foreign tourists and the people of Indonesia. As humans who interact in the community, will create good relationships that are individual or collective, and one individual relationship is a relationship between a man with women in marital ties. The marriage in question is mixed marriage and in the language of the law is a marriage between two people who in Indonesia are subject to different laws, because of differences in citizenship and one of the Indonesian citizens (Article 57 of Act Number 1 of 1974).

Mixed marriages conducted in tourist areas such as Cianjur, Tangerang in this case in Tigaraksa, Bali, and Batam. The four regions can be used as research objects because they are categorized as areas where many foreign nationals enter Indonesia through tourism and interact with the community through marriage. Cianjur has mountain topography so that this area is always covered with cool weather but also no less interesting is the beauty of the beach which is quite promising for foreign tourists. In the World of Bali is known as a tourist destination with the uniqueness of various artistic results[7]. Besides that, Bali, as one of the beautiful islands in Indonesia, is not only unique in its art but the natural beauty that promises and the friendliness of its people, which is the bargaining power of tourists coming to Bali, both domestic and foreign. While Batam is one of the regions known as tourist destinations in Indonesia which are relatively good and relatively easy to sell because they meet A3 criteria 
for tourist destinations. A3 which means Attractiveness (attraction), Amenities (supporting/accommodating facilities), and Access[8].This assumption is proven by the arrival of foreign tourists around two million tourists every year. The Great Batam area, which covers the Riau islands and its surroundings, is the gateway of two million foreign tourists who come to Indonesia, and Batam is one of the three tourism destinations in Indonesia after Bali and Jakarta, and contributes nearly 90 percent of tourists who arrive. to Indonesia [8].Based on the facts above, social interactions occur a lot through mixed marriages, almost every year around 200 couples do mixed marriages[9]. At the Office of Religion Affairs in Sekupang District, for example, mixed marriages were recorded in 2018 from January to August 2018, 10 couples with different nationalities did mixed marriages at the local Religion Affairs Office[10]. This fact shows that Batam is an area where many people do mixed marriages with foreign nationals[11].In the last three years at the Batam Religious Court, there is no data on its marriage, it is because of mixed marriages that are done legally rather than marriage underhand. Legal means the marriage is in a religious affairs office in Batam City and has authentic evidence in the form of a marriage book issued from the local religious affairs office[12].

\subsection{Reasons for Marriage in Mixed Marriage in the Decision of the Religious Court in Indonesia}

The study of itsbat marriage in mixed marriages in this research is limited to religious judges in tourist areas and other regions. Religious Courts in tourist areas include the Religious Courts in the Bali Region. While the religious courts in other regions are considered sufficient to represent the events of itsbat marriage in mixed marriages, namely the Cianjur Religious Court and the Tigaraksa Religious Court. Religious Courts in the Bali region are seen as courts in tourist areas. As understood, Bali is a tourist destination that is very well known to foreign countries. Many foreign nationals who come to Bali come from various countries including citizens of Australia, China, Korea, Japan and also European countries such as the Netherlands and France. Therefore, the social interaction of local communities including Indonesian women who are Muslim, especially those on the coast, meet with foreigners to become easy and the opportunity to establish love that leads to marriage can no longer be avoided. When foreigners and Indonesian citizens get married, there are those who are registered at the Office of Religious Affairs in the local sub-district and some are not registered. This study will explore further the reasons why they propose itsbat marriage to a religious court and the reasons why a mixed marriage between foreigners and Indonesian citizens is not registered. One of the religious courts in the Bali region studied was the Denpasar Religious Court, the Bandung Religious Court, and the Tabanan Religion Court. Table 1 explains about the reasons for itsbat marriage applicants in a mixed marriage.

Table 1. Marriage Applicants

\begin{tabular}{|c|c|c|c|c|c|}
\hline No & Nomor Perkara & Pemohon I & Pemohon II & $\begin{array}{l}\text { Alasan Permohonan } \\
\text { Itsbat Nikah }\end{array}$ & $\begin{array}{l}\text { Tahun } \\
\text { Perkawinan }\end{array}$ \\
\hline 1 & $\begin{array}{l}0015 / \\
P d t . P / 2015 / P A D p s\end{array}$ & $\begin{array}{l}\text { WNA asal } \\
\text { Belanda }\end{array}$ & Denpasar & $\begin{array}{l}\text { Memperoleh akta nikah } \\
\text { \& akte lahir }\end{array}$ & $\begin{array}{ll}\text { Menikah } & d i \\
\text { Pangandaran } & \\
\text { tahun 2013 }\end{array}$ \\
\hline 2 & $\begin{array}{l}0025 / P d t . P / 2015 / P \\
A . B d g\end{array}$ & $\begin{array}{l}\text { WNA asal } \\
\text { Inggris }\end{array}$ & Kuta & Memperoleh akta nikah & $\begin{array}{l}\text { Menikah di Kuta } \\
\text { tahun } 2013\end{array}$ \\
\hline 3 & $0008 / P d t . P / 2016 / P$ & WNA asal & Kuta & Memperoleh akta nikah & Menikah tahun \\
\hline
\end{tabular}




\begin{tabular}{|c|c|c|c|c|c|}
\hline No & Nomor Perkara & Pemohon I & Pemohon II & $\begin{array}{l}\text { Alasan Permohonan } \\
\text { Itsbat Nikah }\end{array}$ & $\begin{array}{l}\text { Tahun } \\
\text { Perkawinan }\end{array}$ \\
\hline & $A . B d g$ & Korea & & & 2010 di Kuta \\
\hline 4 & $\begin{array}{l}\text { 0006/Pdt.P/2017/P } \\
\text { A.Bdg }\end{array}$ & $\begin{array}{l}\text { WNA asal } \\
\text { Belanda }\end{array}$ & Kuta & Memperoleh akta nikah & $\begin{array}{l}\text { Menikah tahun } \\
2002 \text { di Bojong } \\
\text { soang-Kab Bdg }\end{array}$ \\
\hline 5 & $\begin{array}{l}0019 / P d t . P / 2017 / P \\
\text { A.Bdg }\end{array}$ & $\begin{array}{l}\text { WNA asal } \\
\text { New } \\
\text { Zealand }\end{array}$ & Kuta & $\begin{array}{l}\text { Memperoleh akta } \\
\text { nikah }\end{array}$ & $\begin{array}{l}\text { Menikah tahun } \\
2010 \\
\text { pusakanagara } \\
\text { subang }\end{array}$ \\
\hline 6 & $\begin{array}{l}1172 / P d t . P / 2016 / P \\
\text { A.Cjr }\end{array}$ & $\begin{array}{ll}\text { WNA } & \text { asal } \\
\text { China } & \\
\end{array}$ & Cianjur & $\begin{array}{l}\text { Memperoleh Akta } \\
\text { Nikah }\end{array}$ & $\begin{array}{l}\text { Menikah Tahun } \\
2010\end{array}$ \\
\hline 7 & $\begin{array}{l}0004 / P d t . P / 2018 / P \\
\text { A.Cjr }\end{array}$ & $\begin{array}{l}\text { WNA asal } \\
\text { Pakistan }\end{array}$ & Cianjur & $\begin{array}{l}\text { Memperoleh akta } \\
\text { nikah \& kejelasan } \\
\text { status anak }\end{array}$ & $\begin{array}{l}\text { Menikah Tahun } \\
2003\end{array}$ \\
\hline 8 & $\begin{array}{l}0151 / P d t . P / 2018 / P \\
\text { A.Cjr }\end{array}$ & $\begin{array}{ll}\text { WNA asal } \\
\text { Saudi } \\
\text { Arabia } \\
\end{array}$ & Cianjur & $\begin{array}{l}\text { Memperoleh akta } \\
\text { nikah \& kejelasan } \\
\text { status anak }\end{array}$ & $\begin{array}{l}\text { Menikah tahun } \\
2003\end{array}$ \\
\hline 9 & $\begin{array}{l}\text { 004/Pdt.P/2017/P } \\
\text { A.Tgrs }\end{array}$ & $\begin{array}{ll}\text { WNA } & \text { Asal } \\
\text { Mali } & \\
\end{array}$ & $\begin{array}{l}\text { Tangerang } \\
\text { Selatan }\end{array}$ & $\begin{array}{l}\text { Memperoleh akta } \\
\text { nikah }\end{array}$ & Menikah 2015 \\
\hline 10 & $\begin{array}{l}\text { 616/Pdt.P/2017/P } \\
\text { A.Tgrs }\end{array}$ & $\begin{array}{l}\text { WNA asal } \\
\text { Thiongkok }\end{array}$ & $\begin{array}{l}\text { Tangerang } \\
\text { Selatan }\end{array}$ & $\begin{array}{l}\text { Memperoleh } \\
\text { nikah }\end{array}$ & Menikah 2015 \\
\hline 11 & $\begin{array}{l}\text { 070/Pdt.P/2018/P } \\
\text { A.Tgrs }\end{array}$ & $\begin{array}{l}\text { WNA Asal } \\
\text { Oman }\end{array}$ & $\begin{array}{l}\text { Tangerang } \\
\text { Selatan }\end{array}$ & $\begin{array}{l}\text { Memperoleh } \\
\text { nikah }\end{array}$ & Menikah 2017 \\
\hline 12 & $\begin{array}{l}\text { 184/Pdt.P/2018/P } \\
\text { A.Tgrs }\end{array}$ & $\begin{array}{ll}\text { WNA asal } \\
\text { Korea }\end{array}$ & $\begin{array}{l}\text { Tangerang } \\
\text { Selatan }\end{array}$ & $\begin{array}{l}\text { Memperoleh } \\
\text { nikah }\end{array}$ & Menikah 2011 \\
\hline 13 & $\begin{array}{l}\text { 0362/Pdt.P/2018/P } \\
\text { A.Tgrs }\end{array}$ & $\begin{array}{l}\text { WNA asal } \\
\text { Saudi Arabi }\end{array}$ & $\begin{array}{l}\text { Tangerag } \\
\text { Selatan }\end{array}$ & $\begin{array}{l}\text { Memperoleh } \\
\text { nikah }\end{array}$ & 2013 \\
\hline
\end{tabular}

Based on Table 1 above, the reason for the applicant to propose marriage itsbat in a mixed marriage is the same, namely to obtain a legal identity in the form of a marriage certificate. The position of a marriage certificate for a mixed marriage partner as a legal document is very important. This is supported by several findings from interviews with Badung religious court judges, the Denpasar Religious Court, and the Tabanan Religious Court that the motives of foreigners marry Indonesian women to obtain the ease of residence permit.

Based on the results of the interview, the reasons for the male foreigners marrying Indonesian women on the grounds include that Indonesian woman are so loving and caring to men foreigners. Unlike other foreign women who according to foreign men often demand gender equality rights so they do not want to get married. Also, foreign women do not want to want children while Indonesian women are resigned and kind and want to get pregnant for their marriage. The submission of divorce that they do occurs between the ages of 5 and ten years of marriage. The causative factors vary, among others, is dissatisfaction with the wife, such as asking for money to continue shopping or being sick. Many foreign marriages with Indonesians is done with a sharp age difference, for example, a 60-year-old woman's husband and a 25 -year-old Indonesian woman. For foreign men, with the legality of their marriage, residency permits and other impacts can be easily owned so it is quite logical that marriages that are not recorded among foreigners are marriages that are unfavorable for both parties, where the foreigners themselves need marital legality as well Indonesian wives need it for the future of their marriage. 
The existence of marriage certificate documents for marriage in Indonesia is very central. Is the marriage carried out between Indonesian citizens and different citizens? Marriage and legal identity have a very close relationship. The people who are married and then the marriage is recorded, then they have the right to obtain legal identity in the form of a marriage certificate. Conversely, those who are married but cannot interpret or show a marriage certificate, the marriage will result in the difficulty of obtaining another legal identity, such as a birth certificate.

The legal identity referred to here is a legal proof of identity owned by a person, one of which is a marriage certificate/book. The marriage certificate/book in Indonesia is a document that can be issued by two authorized parties: the Office of Religious Affairs for people who are Muslim and the Office / Service of Civil Registry for non-Muslims. This marriage certificate/book is a legal document that proves the marriage status of a couple based on marriage registration in accordance with Law No. 1 of 1974 concerning Marriage and Law No. 23 of 2006 concerning Population Administration in conjunction with Law Number 23 of 2013.

A person can obtain legal identity rights in the form of a birth certificate if the husband and wife have other legal identity documents, namely marriage certificates. Communities that do not have a legal identity in the form of a marriage certificate will naturally have very serious consequences, namely having an impact on legal identity ownership in relation to access to education, health, social assistance, and legal protection.

Therefore, people who do not have a legal identity document in the form of a marriage certificate, they can apply to obtain the marriage certificate through itsbat marriage to a religious court. Initially in accordance with Law No. 7 of 1989 and Law No. 3 of 2006, Marriage Marriage is only done for marriages that occur before Law No. 1 of 1974 concerning Marriage and run according to other regulations. This is based on the assumption after the enactment of Law No. 1 of 1974 concerning Marriage no more marriages are not recorded. This assumption turns out to be wrong. Caused by several factors, marriages that are not recorded or often referred to as sirri marriages are increasingly increasing. In some areas such as Karawang, Polewali, Bontang, and several other regions the regional head or local government must intervene to overcome hundreds or even thousands of married couples whose marriages are not recorded.

The applicants for marriage bona fide submitting to the religious court are basically the reason for the request to obtain a legal basis for obtaining a marriage certificate. This is where they really think it is important that the marriage certificate is owned by them in their marriage. This unregistered marriage brings harm to the husband, wife, and children of the family couple. Husbands and wives of unregistered marriages cannot file any rights to each other, and children will find it difficult to obtain birth certificates and other important documents. The only way out of making this unregistered marriage to be registered and have a marriage certificate or book is to apply for the Marriage Itsbat to the Religious Court.

A number of data show that the number of itsbat marriage cases (marriage ratification) in 359 Religious Courts in Indonesia tripled. In 2013, the Religious Courts tried more than 35,000 marriage cases. The number of cases tried through village-level circuit courts doubled, and the Religious Court tried more than 23,000 cases through a mobile court in 2012. These data indicate that the involvement of religious courts in serving legal identity rights is very large so that it is reasonable if in the future there is a mechanism that makes it easier for the poor to obtain the legal identity rights[13]. Because of the urgency of the marriage certificate as a legal document, every married couple who do not have it will be settled through the door of its marriage, as well as for applicants in mixed marriages that will entail marriage. 


\subsection{Itsbat Marriage Process in Mixed Marriage in Tourism Areas in Indonesia}

There is no fundamental difference regarding the process of examining legal cases of marriage and itsbat marriage in mixed marriages. As in the examination of itsbat ordinary marriage, itsbat marriage examination process in mixed marriages is done the same as the procedure for filing a divorce case, divorce, inheritance, guardianship, and others. This means that the procedure for filing marriage cases in marriage between fellow citizens of Indonesia and in mixed marriages is the same as the procedure for submitting other cases. Because basically the procedure for applying for itsbat marriage in Law No. 1 of 1974 and the Compilation of Islamic Law is not clearly regulated.

According to the Guidelines for the Implementation of Duties and Administration of Religious Courts in Book II of the 2011 Revised Edition, the marriage itsbat process is carried out in several stages. Applications for marriage ratification or itsbat marriage can be carried out by both husband and wife or one of the husband and wife, children, guardian of marriage and other parties with interest in the marriage to the Religious Court or the Syar'iyah Court in the jurisdiction of the applicant residing, and marriage authorization application or the marriage's itsbat must be completed with clear and concrete reasons and interests[14].

The process of checking the application for its marriage proposal submitted by both husband and wife is voluntary; the product is in the form of determination. If the content of the decree rejects the application for validation or itsbat marriage, the husband and wife together or husband, each wife can file a cassation. The process of examining the application for its marriage proposal filed by a husband or wife is controversial by placing a wife or husband who does not submit an application as a party to the respondent, the product in the form of a decision and against the decision can be appealed and appealed. If in the process of examining the validation application or its marriage confirmation, it is known that her husband is still bound in a legal marriage with another woman, then the previous wife must be made a party (the respondent) in the case. If the applicant does not want to change his application by entering the previous wife as a party, the application must be declared unacceptable.

Requests for marriage ratification filed or carried out by a child, guardian of marriage and other interested parties must be contextual, by placing husband and wife and / or other heirs as the respondent. A husband or wife who is left dead by his wife or husband can submit a request for endorsement or its marriage is contingent. By placing other heirs as the defendant's party, the product is in the form of a decision, and the appeal can be appealed and appealed upon. In the event that a husband or wife is left dead not knowing that there are other heirs other than himself, then the marriage application is submitted voluntarily, the product is in the form of a stipulation. If the application is refused, then the applicant can file a cassation.

Other people who have interests and do not become parties in the case of marriage authorization applications, can fight against the Religious Courts or the Shariah Court that decide, after knowing that there is an endorsement or itsbat marriage. As in the case, the other person has sufficient evidence that the person who has obtained his marriage authorization turns out to be a sibling or sibling or a mother and / or sister after each other, the matter of which his marriage was previously hidden regarding his nasab relationship status. Other people who have interests and do not become parties in the case of the marriage authorization application can submit an intervention to the Religious Court or the Shariah Court that examines the case of marriage ratification as long as the case has not been decided. As in the case, the applicant did not include her husband's previous wife, only included her husband's children, so the previous wife submitted an intervention to the case of the marriage ratification 
that was underway. Other parties who have a legal interest and do not become parties to the case for the ratification application or the marriage confirmation, while the application has been decided by the Religious Court or the Shariah Court, can file a lawsuit for cancellation of the marriage that has been approved by the Religious Court or the Shariah Court .

Itsbat marriage examination process as stated above applies also to itsbat examination for marriage in mixed marriages. When referred to about mixed marriage practices that occur in tourist areas such as Bali, the process begins with the introduction of applicants at tourist attractions, such as karoeke, beaches, and hotels. Mixed marriage in the Province of Bali, especially in the District of South Kuta, is an average of 5 couples each month from the number of marriages per month as many as 35 couples, so that if those who carry out mixed marriages are averaged over 1 year. up to $15 \%[15]$, [16].

Thus, the process of examining itsbat marriage in mixed marriages is passed as an examination of ordinary (not mixed) itsbat marriage. Amar in the application for itsbat marriage in a mixed marriage in the form of granting and rejecting the petition of the applicant. If the application for itsbat marriage in a mixed marriage is to be granted, the conditions and the pillars of marriage must be fulfilled by the applicants. In addition, the applicants must be able to prove in front of the Panel of Judges that evidence can support the validity of the marriage, such as the existence of guardians and witnesses. If the provisions as mentioned above have been fulfilled, then the marriage itsbat application can be granted by the Panel of Judges.

\subsection{Impact of Establishment of Marriage Marriage in Mixed Marriage on Marital Status, Status of Children and Status of Marriage Property}

Based on the results of research in the Religious Courts in tourist areas in Indonesia, and based on itsbat marriage for couples who engage in mixed marriages, there are various reasons proposed and have an impact on the legal strengthening of marriages carried out which impact on other legal issues, such effects

\section{a) The legal power of marriage that takes place before the marriage itsbat}

The marriage process which has been taken through the means regulated in the law, and has been determined by the Religious Court judge, the marital status of the person who carried out the marriage has legal force. Likewise for children born from marriages which have been referred to the Religion Court also get legal recognition and are entitled to other rights, such as the right to obtain a birth certificate and other material rights. If marriage registration is a formal requirement that is procedural and administrative, the itsbat marriage can also provide a more concrete guarantee legally for the rights of husband and wife also for children born, other impacts such as after the divorce, the determination of itsbat marriage is the legal basis for the marriage registration which gave birth to legal certainty of the marriage that occurred. For mixed marriages that have committed its marriage to the religious court in the jurisdiction of the Religious Courts according to the research conducted, their marriages are legally enforceable. And to further have the rights and obligations in accordance with applicable law in Indonesia. 


\section{b) Legal strength of the child born of the marriage}

Often the filing of the marriage's itsbat is accompanied by the legal submission of children born from marriages that are not recorded with the aim of obtaining the same endorsement as its marriage certificate, this is due to the emergence of phenomena contained in the community if the child cannot be recognized by the civil registry as a child born of a legal marriage, there needs to be careful consideration because many phenomena in certain regions in Indonesia do not want to accept if their child is stated to be born from a mother and there is only civil relations with the mother without mentioning the name of the father of the child[17].One proof that supports the proof of the child is actually only in the hands of a wife who knows who the seeds they contain, but this condition will bring discrimination and corner the women by not closing the possibility of giving men the opportunity to deny, and prove the parties the woman is not an easy thing to do that puts women in despair[18].

The rights of children are a gift without differentiating the child himself and are inherently authentic to the child, so if the juridical barriers to the marriage of his parents have legalized his marriage through itsbat marriage the child's rights are automatically inherited due to a legal marriage including his private rights. Human rights in Islamic law are highly valued which are known in the general public with human rights, so it can be seen in the opinion of al-Ghazali with the concept of al-kulliyat al-Maqashid al-Khamsah or five universal basic rights, namely hifdhu al-nafs, hifdhu al-Aql, hifdhu al-Din, hifdhu al-Mal and hifdzu al-Nasl, the itsbat of mixed marriages is a form of respect for protection of offspring and in turn is a form of protection for offspring or children born of marriage[19].

c) The legal power of property and wealth obtained since the marriage takes place, for example, joint property, right to live, rights to inheritance from a spouse who one of them dies.

In line with the marriage's itsbat which affects the legal certainty of marital status and legality of children born due to mixed marriages conducted outside the recording of Marriage Registration Officer or not having authentic evidence in the form of marriage certificate, the marriage will also provide legal certainty (principle of legal security) to the status of marital property, and with the existence of the marriage itsbat the settlement of the marriage property dispute can refer to the prevailing legislative norms. With the existence of such legal certainty, guarantees for community members will not be treated arbitrarily because it is in accordance with applicable law. The marriage that has legal power influences the existence of material rights relations between husband and wife and children born from legitimate marriages, including material rights if the marriage breaks up either due to the termination of marriage due to divorce or because of death. These material rights include: wife's right to mut'ah [20]; right to mutual inheritance[21]-[27]; and right to joint property[21], [28]-[31].

\section{Conclusion}

The meaning of marriage itself means that marriage is established. In the provisions of the legislation concerning marriage itsbat there is no clear understanding, but can be understood from the provisions of Article 7 Compilation of Islamic Law concerning marriage registration. Itsbat marriage is a legal process to get marital legality conducted between a man and woman whose marriage cannot be proven by authentic evidence in the form of a marriage certificate 
issued by the Marriage Registration Officer from the Office of Religion Affairs, juridically the application of itsbat marriage to a marriage that cannot be proven authentic regulated in Act Number 1 of 1974 namely to take care of the interests of divorce, because the missing deed and others constitute deviations from the statutory provisions of Article 49 paragraph (2) of Act Number 7 of 1989 jo. Law Number 3 of 2006 jo. Law Number 50 of 2009 concerning Religious Courts, and their explanation, but because it is very much needed, the Religious Court judge discretion by granting the itsbat marriage based on the provisions of Article 7 paragraph (3) letter e Compilation of Islamic Law, with the aim of benefit for the marriage to have legal force.

Juridically its mixed marriage itsbat in tourist areas in Indonesia legal considerations Religious Court judges not only use written law as in the Compilation of Islamic Law Article 3 paragraph (3) letter e which is used as the reason for ijtihad judges to grant their bat mixed marriage in tourist areas in Indonesia, but more emphasis on other aspects so that from various formulation of judges' considerations, disparities can occur. This disparity is related to the fact that the event was presented to him. However, by reading the posita submitted by the applicant, especially the applicants whose marriages are fulfilled, the conditions and conditions are fulfilled, disparity in consideration should not occur so that if it is said that the spirit and heart of the judge's decision lies in its consideration it can be read and understood more easily. The following is presented a table of differences in judges' consideration in examining itsbat mixed marriages.

Judges' considerations are considerations before the judge drops the ruling. In legal view, the judge is seen as a figure of all-knowing, who in this case knows about the law of itsbat marriage and has the freedom to find law if it is not found in the legislation. Therefore, all applications of the applicants for itsbat marriage in mixed marriages will be considered by the judge regarding the law. The Judge of the Religious Courts should "understand Indonesian law as seen from the roots of the dominant philosophy of thought in reality about the meaning of what is understood as law and what is believed to be the source of the force of law.

The process of examining itsbat marriage in mixed marriages is carried out as the examination of ordinary marriage (not mixed). Amar in the application for itsbat marriage in a mixed marriage in the form of granting and rejecting the petition of the applicant. If the application for itsbat marriage in a mixed marriage is to be granted, the conditions and the pillars of marriage must be fulfilled by the applicants. In addition, the applicants must be able to prove in front of the Panel of Judges that evidence can support the validity of the marriage, such as the existence of guardians and witnesses. If the provisions as mentioned above have been fulfilled, then the marriage itsbat application can be granted by the Panel of Judges.

Marriage that has legal certainty (principle of legal security and rechtzheheid, the state guarantees the rights and obligations of every citizen including those who mix in tourist areas in Indonesia by the state or authorities, these rights and obligations are an impact on marriage determination namely itsbat marriage which has been granted by the Religious Court with various legal reasons for the application of itsbat, then the effect of its marriage has the right and obligation to strengthen marriage itself will arise rights and obligations related to material rights, for example the right of livelihood, joint property rights, malwaris inheritance rights and so on. Another aspect which is used as a reason for the submission of itsbat is to obtain legal force for children born from mixed marriages which are carried out outside of the recording of the Marriage Registration Officer, the law enforcement affects the child's right to obtain a birth certificate so that the administrative rights that are needed are also fulfilled. Other rights such as guardianship and the right to obtain an inheritance from both parents if both or one of them dies. 
The high level of mixed marriages in tourist areas in Indonesia and the low level of public awareness to carry out itsbat marriage from mixed marriages not recorded by the Marriage Registrar has an impact on the loss of rights for Indonesian citizens who engage in mixed marriages, therefore the need for rules a more stringent and efficient law for mixed marriages that were not recorded by Marriage Registration Officers, as well as the need for socialization to the public related to the unrecorded marriage law which gave a barrier to the perpetrators of the marriage.

The legal reason used as a legal consideration by the judge in granting itsbat mixed marriages in Indonesia besides ijtihad interpreting Article 7 paragraph (3) letter e Compilation of Islamic Law raises the disparity of decisions. Therefore it is necessary to have a special article in the legislation or in the Compilation of Islamic Law which regulates formal juridical basis as a legal consideration by judges in the Religious Court in Indonesia in granting itsbat marriage for mixed marriages specifically so that the legal reason for the judge to make Article 7 paragraph (3) letter e Compilation of Islamic Law as a presumption to legalize the stipulation of mixed marriages in Indonesia, if needed, a more specific article is needed to regulate itsbat marriage for mixed marriages in Indonesia, so that the article is considered as the reason for all itsbat marriage to various problems in marriage.

Acknowledgements. We would like to say thank you to Research and Publication Centre of UIN Sunan Gunung Djati Bandung for appreciation and funding this research.

\section{References}

[1] M. J. Al-Mughniyah, al-Fiqh 'Ala madzahibi al-Khomsah. Beirut: Dar al-Kitab alIlmiyah.

[2] D. Syafriyanto, "Pelaksanaan itsbat nikah di Pengadilan Agama Semarang setelah Berlakunya Undang-Undang Nomor 1 Tahun 1974,” Universitas Negeri Semarang, Semarang, 2013.

[3] N. R. Yunus, "Proses Pemeriksaan Pengesahan Nikah Pada Pengadilan Agama," Makasar, 2013.

[4] M. Yasmin, "Akibat Perkawinan CampuranTerhadap Status Anak dan Harta Benda Yang Diperoleh Sebelum dan Sesudah Perkawinan Campuran Studi Banding Indonesia dan Malaysia," Jakarta, 2015.

[5] B. Bungiin, Metodologi Penelitian Kualitatif, Metodologi Penelitian ke Arah Ragam Kontemporer. Jakarta: Raja Grafindo, 2004.

[6] S. Agustina, "6 Hal yang Membuat Turis Asing Betah Liburan di Indonesia, Malah Pengin Balik Lagi!," Tribun Travel. [Online]. Available: http://ravel.tribunnews.com/2017/02/12/6-hal-yang-membuat-turis-asing-betahliburan-di-indonesia-malah-pengin-balik-lagi.

[7] Anonymous, "Provinsi Bali." .

[8] A. Yahya, "Batam dan Bintan Sempurna Sebagai Destinasi Wisata," 2018. .

[9] K. K. Batam, "Hasil Wawancara dengan kepala Kandepag Kota Batam,” Batam, 2018.

[10] Kantor Urusan Agama Sekupang, Daftar Laporan Perincian NTCR Kantor Urusan Agama Sekupang Kota Batam. Batam: Kantor Urusan Agama Sekupang Kota Batam, 2018.

[11] H. Hamizar, "Wawancara Kepala Kantor Urusan Agama," Sekupang.

[12] Basuni, "Wawancara dengan Ketua Pengadilan Agama Batam," Batam, 2018. 
[13] C. Sumner, Studi Dasar AIPJ Tentang Identitas Hukum Jutaan Orang tanpa Identitas Hukum Di Indonesia. Jakarta: Australia Indonesia Partnership for Justice, 2014.

[14] Mahkamah Agung, Pedoman Pelaksaan Tugas Dan Administrasi Peradilan Agama. Jakarta: Mahkamah Agung, 2011.

[15] Masruhan, "Hasil Wawancara," 2018.

[16] Karyadi, "Hasil Wawancara Panitera," 2018.

[17] A. S. Alam, "Beberapa Permasalahan Hukum di Lingkungan UNDILAG, Disampaikan dalam Rapat Kerja Nasional Mahkamah Agung RI Jajaran Pengadilan Tingkat Banding dari Empat Lingkungan Peradilan seluruh Indonesia,” Jakarta, 2009.

[18] I. Hasani, Referensi Bagi Hakim Pengadilan Agama Tentang Kekerasan dalam RumahTangga, Komnas Per. Jakarta, 2008.

[19] M. F. Mas'udi, Syarah Konstitusi UUD 1945 Dalam Perspektif Islam. Jakarta: Pustaka Alvabet dan Lembaga Kajian Islam dan Perdamaian (LaKIP), 2011.

[20] A. Djazuli, Kaidah-Kaidah Fikih, I. Jakart: Kencana Prenada Media Group, 2006.

[21] O. Salman, Hukum Waris Islam. Bandung: Refika Aditama, 2010.

[22] S. K. Sanderson, Makro Sosiologi, Sebuah Pendekatan Terhadap Realitas Sosial, 2nd ed. Jakarta: PT. Raja Grafindo Persada, 2003.

[23] I. Q. Al-Maqdisy, Al-Mughny. Kairo: Dar al-Manar, 1367.

[24] Direktorat Pembinaan Badan Peradilan Agama Islam, Laporan Hasil Seminar Hukum Waris Islam. Jakarta: Direktorat Pembinaan Badan Peradilan Agama Islam, Departemen Agama RI, 1982.

[25] A. Sosroatmodjo and W. Aulawi, Hukum Perkawinan Indonesia. Jakarta: Bulan Bintang, 1978.

[26] M. bin I. al Kahlani, Subulussalam. Jeddah: Harman, 1960.

[27] M. I. 'Ali Al-Syaukani, Naylual-Awtor. Mesir: Mustafa al-Babi al-Halabi.

[28] Y. Musa, al-Tirkatu wa al-Mirats fi al-Islam. Kairo: Dar al-Ma’arif, 1960.

[29] S. Thalib, Hukum Kekeluargaan di Indonesia. Jakarta: Bulan Bintang, 1983.

[30] W. Prodjodikoro, Hukum Waris di Indonesia. Bandung: Sumur Bandung, 1986.

[31] M. dan A. Wahid, Hukum Kewarisan Islam Sebagai pemburan Hukum Positif di Indonesia. Jakarta: Sinar Grafika, 2009. 